\title{
The evolution of antimicrobial resistance in respiratory pathogens in Canada: What are the clinical consequences?
}

\author{
Donald E Low MD FRCPC
}

\begin{abstract}
DE Low. The evolution of antimicrobial resistance in respiratory pathogens in Canada: What are the clinical consequences? Can J Infect Dis 1998;9(Suppl E):10E-15E.

The use of antimicrobial agents has led to reductions in illnesses and deaths from a variety of infectious diseases. Antimicrobial resistance has followed the introduction of almost every new antimicrobial agent and is now emerging as an important public health problem, especially in respiratory tract pathogens in the community. During the past decade in Canada, a rapid and relentless increase in antimicrobial resistance in Streptococcus pneumoniae and Haemophilus influenzae has been witnessed. Adverse implications as a result of the treatment of an infection with an antibiotic to which the offending pathogen is resistant have been recognized in only a few infectious disease syndromes (eg, bacterial meningitis). More often, resistance in vitro does not result in resistance in vivo (eg, respiratory tract infections). Therefore, before recommendations regarding empirical or directed therapy are changed, it is essential that evidence to support those decisions is obtained. More important, the prevention and control of such resistance must be addressed by reducing the burden of antibiotic selective pressure by curtailing inappropriate antibiotic use.
\end{abstract}

Key Words: Antimicrobial resistance, Beta-lactams, Community-acquired pneumonia, Fluoroquinolones, Haemophilus pneumoniae, Macrolides, Streptococcus pneumoniae, Trimethoprim/sulfamethoxazole

\section{L'évolution de la résistance aux antibactériens chez les pathogènes des voies respiratoires au Canada : quelles en sont les conséquences cliniques?}

RÉSUMÉ: L'utilisation d'antibactériens a permis de réduire les maladies et les décès imputables à une gamme de maladies infectieuses. La résistance aux antibactériens a fait suite à l'introduction de presque chaque nouvel antibactérien et devient maintenant un problème grandissant de santé publique, surtout en ce qui concerne les pathogènes des voies respiratoires extra-hospitaliers. Au Canada, au cours de la dernière décennie, on a noté une augmentation rapide et implacable de la résistance de Streptococcus pneumoniae et Haemophilus influenzae aux antibactériens. Les implications indésirables qui résultent du traitement d'une infection avec un antibiotique auquel le pathogène incriminé est résistant ont été mises en évidence seulement dans quelques syndromes de maladies infectieuses (par exemple, la méningite bactérienne). Le plus souvent, une résistance in vitro ne résulte pas en une résistance in vivo (par exemple, les infections des voies respiratoires). Par conséquent, avant de modifier les recommandations concernant la thérapie dirigée ou empirique, il est indispensable d'avoir des preuves pour étayer ces décisions. De plus, on doit se pencher sur la prévention et le contrôle de ce type de résistance en allégeant le fardeau de la pression de la sélection exercée par l'antibiothérapie par une réduction de l'usage inapproprié des antibiotiques.

$\mathrm{D}$ uring the past decade in Canada, there has been a rapid and relentless increase in antimicrobial resistance in Streptococcus pneumoniae and Haemophilus influenzae. These two bacterial pathogens are frequently associated with respiratory tract infections, including community-acquired pneumonia (CAP), in both children and adults $(1,2)$. The consequences of infections due to resistant strains include the likelihood of inappropriate initial therapy, the need to sometimes use less effective alternative antimicrobials and increased healthcare costs. Because clinicians are usually un- 
aware of the pathogen or its antimicrobial susceptibility when initially deciding on the therapy, it is important to know the rates of resistance in the community and the consequences of using an antimicrobial to which the offending organism is resistant. Such knowledge will help physicians decide when it is appropriate to change empirical therapy.

\section{DETERMINING THE CONSEQUENCES OF ANTIMICROBIAL RESISTANCE}

It is often difficult to measure the effect of inappropriate treatment of an infection with an antibiotic to which the offending organism is resistant. There are a number of clinical infectious syndromes for which the benefit of antimicrobial therapy is questionable. Criteria that determine the resistance of an organism to a particular antimicrobial or group of antimicrobials may not always correlate with treatment outcomes. Finally, comorbid illnesses or physiological processes are often not accounted for when attempting to determine whether treatment failure is due to antimicrobial resistance.

Infections that are caused by organisms that are resistant to the antimicrobial used may appear to respond because the natural history of the infection is often to resolve spontaneously. Examples include acute sinusitis and mild to moderate acute exacerbation of chronic bronchitis (3-6). van Buchem et al (4) randomly assigned patients that had been diagnosed as having acute maxillary sinusitis to placebo or amoxicillin. They found that amoxicillin did not influence the clinical course or the frequency of relapses. Anthonisen et al (3) found that antibiotics were ineffective in mild acute exacerbations of chronic bronchitis. They did, however, find a difference in the success rate between antibiotic and placebo for the more severe exacerbations; deterioration in patients with more severe exacerbations was over twice as common with placebo as with antibiotic. The benefit of antimicrobial therapy has been clearly established for bacterial pneumonia (7). In the preantibiotic era, over $80 \%$ of CAP was due to $S$ pneumoniae, with mortality rates of $20 \%$ to $40 \%(7,8)$. In the antibiotic era, the overall mortality rates of CAP are less than $6 \%$ and for $S$ pneumoniae are less than $15 \%(9,10)$. However, there is also evidence to suggest that the mortality of bacteremic pneumococcal pneumonia has not changed over the past several decades, even with additional therapeutical and supportive measures, including intensive care unit support $(11,12)$.

The clinical relevance of resistance in vitro may depend on the site of infection and the degree of resistance. What constitutes resistance of an organism to an antibiotic in vitro may not be relevant for the site at which the organism is causing the infection. Penicillin therapy is frequently ineffective in meningitis caused by pneumococci exhibiting intermediate resistance because of the relatively low concentrations of penicillin achievable in the cerebrospinal fluid. However, there is no convincing evidence that therapy with penicillin or an equally active beta-lactam antibiotic is ineffective in pneumonia or bacteremia due to pneumococci that are intermediately or highly resistant to penicillin (13).

Finally, when trying to assess the relationship between an- tibiotic activity and outcome, several factors have to be taken into consideration including the type of pathogen, the physiological response by the host and underlying comorbid illnesses. Mortality is closely associated with the etiology of the infection. Patients with Pseudomonas aeruginosa, Staphylococcus aureus and enteric Gram-negative rod pneumonia (eg, Klebsiella species and Escherichia coli) have overall mortalities of greater than $30 \%$ (9). Austrian and Gold (7) found that the mortality rate for type I pneumococcal bacteremia was $8 \%$ for all cases, whereas that for type III infection was 55\%. Despite the benefit seen with the use of antibiotics for the treatment of $S$ pneumoniae bacteremia, the mortality in the first five days of the illness has not been altered (7). Austrian and Gold (7) found that the percentage of patients who had died with bacteremic pneumococcal pneumonia was similar for those patients that were untreated, or treated with penicillin, tetracycline or serum therapy during the first five days of the diagnosis of their illness. In addition, $60 \%$ of all deaths among patients treated with penicillin were found to occur in the first five-day period, despite treatment often being initiated on the first or second day of the illness. This suggests that factors in addition to the pathogen, such as the physiological response by the host, are important regarding outcome. Factors that are independently associated with mortality include the following: age older than 50 years, neoplastic disease, congestive heart failure, cerebrovascular disease, renal disease and liver disease (10).

Despite these observations, there are important interventions that can be made that improve the outcome of the patient with CAP. Leroy et al (14) identified 16 predictors of mortality for severe CAP. Among the factors found in the multivariate analysis, three were found to be attributable to medical interventions: the use of antimicrobial combinations (protective effect); delayed initiation of mechanical ventilation (greater than $12 \mathrm{~h}$ ); and ineffective antimicrobial therapy, as defined by failure of clinical improvement and decrease in fever at $72 \mathrm{~h}$ of treatment. These findings underscore the need not only to provide coverage for all potential etiologies but also to be aware of local resistance rates to ensure the choice of the most effective antimicrobial.

\section{WHEN ANTIMICROBIAL RESISTANCE MAY BE RELEVANT}

When considering the relevance of antimicrobial resistance of the bacterial pathogens that are etiological agents of CAP, it is important to consider whether the agent causes a concomitant bacteremia and the level of resistance of the organism to the antimicrobial. Although $H$ influenzae is often cited as one of the most frequent causes of CAP, it is infrequently isolated from the blood (15). In studies carried out before the introduction of the H influenzae type b vaccine, approximately one-third to one-half of the blood culture-documented cases of $H$ influenzae pneumonia were caused by type $\mathrm{b}(16,17)$. To date in Canada, due to the widespread use of the type b vaccine, the rate of colonization and invasive disease, such as pneumonia and bacteremia, is significantly less in all age groups (18). S pneumoniae is clearly the most important bacterial pathogen causing CAP. Approximately $30 \%$ of all cases of CAP due to 
TABLE 1

Minimal inhibitory concentration (MIC) interpretive standards for Streptococcus pneumoniae according to the January 1998 National Committee for Clinical Laboratory Standards' guidelines (Villanova, Pennsylvania)

\begin{tabular}{lccc}
\hline & \multicolumn{3}{c}{ MIC $(\mathbf{m g} / \mathbf{L})$ interpretive standard } \\
Antimicrobial agent & Susceptible & Intermediate & Resistant \\
\hline Penicillin & $\leq 0.06$ & $0.12-1$ & $\geq 2$ \\
Amoxicillin & $\leq 0.5$ & 1 & $\geq 2$ \\
Erythromycin & $\leq 0.25$ & 0.5 & $\geq 1$ \\
TMP/SMX* & $\leq 0.5 / 9.5$ & $1 / 19-2 / 38$ & $\geq 4 / 76$ \\
Levoflocaxin & $\leq 2$ & 4 & $\geq 8$ \\
Sparfloxacin & $\leq 0.5$ & 1 & $\geq 2$ \\
Grepafloxacin & $\leq 0.5$ & 1 & $\geq 2$ \\
Trovafloxacin & $\leq 1$ & 2 & $\geq 4$ \\
\hline
\end{tabular}

*TMP/SMX Trimethoprim/sulphamethoxazole. Data adapted from reference 21

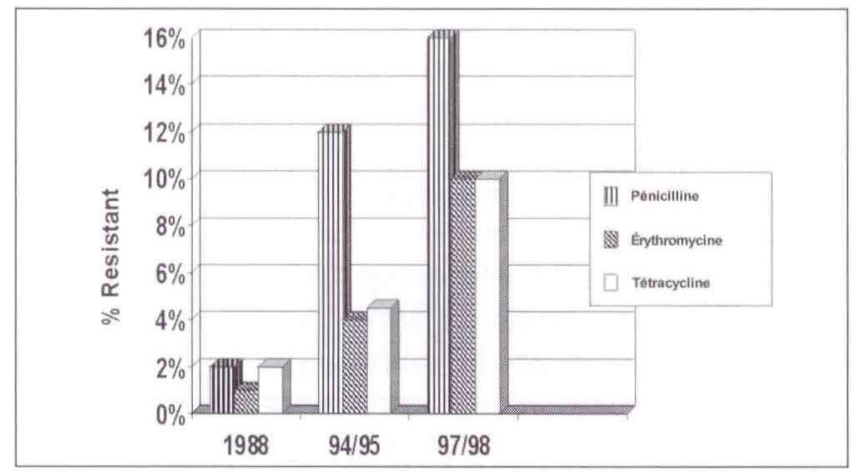

Figure 1) The evolution of multidrug-resistant (intermediate and high resistant) Streptococcus pneumoniae in Canada. Adapted from references 58,70 , personal communication

pneumococci are bacteremic and, therefore, potentially able to cause secondary infections at extrapulmonary sites.

\section{BETA-LACTAMS}

Beta-lactams kill $S$ pneumoniae by binding to the penicillinbinding proteins (PBPS), thereby preventing the bacteria from making new cell wall. Resistance in $S$ pneumoniae is due entirely to the development of low affinity PBPs and not to the production of a beta-lactamase as is resistance in $H$ influenzae (19). Penicillin-susceptible $S$ pneumoniae contain six PBPs. In isolates that have a high level resistance to penicillin, there have been reductions in the affinities of at least three of the PBPs. High level resistance to cephalosporins requires reductions in the affinities of only two PBPs (20). Penicillin resistance in $S$ pneumoniae is subdivided according to the minimal inhibitory concentration (MIC) of the organism. Pneumococci for which the MIC of penicillin is less than $0.1 \mathrm{mg} / \mathrm{L}$ are defined as susceptible, those for which the MIC is 0.1 to $1.0 \mathrm{mg} / \mathrm{L}$ as intermediately resistant, and those for which the MIC is greater than $1.0 \mathrm{mg} / \mathrm{L}$ as highly resistant (Table 1) (21). Currently, the rates of intermediately and highly resistant strains of $S$ pneumoniae in Canada are greater than 14\% (Figure 1).

The use of the oral beta-lactams for the treatment of penicillin-resistant, nonmeningeal invasive pneumococcal in-

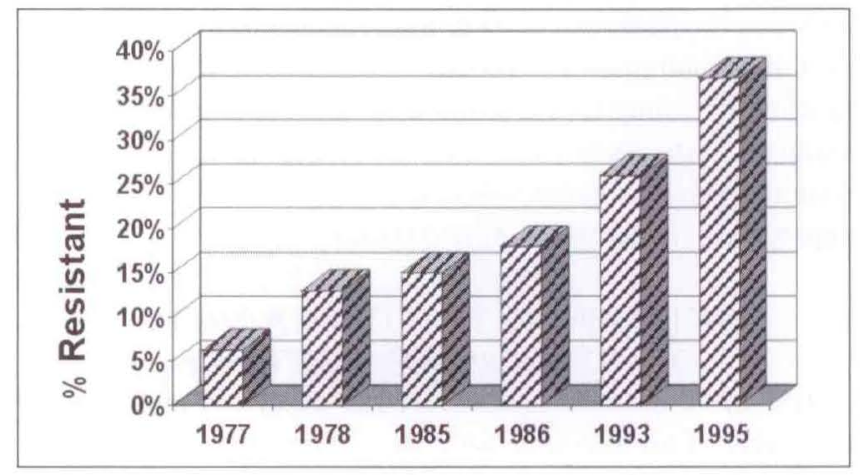

Figure 2) The evolution of beta-lactamase-positive Haemophilus influenzae in Canada. Adapted from references 28,62-65

fections is controversial $(13,22-24)$. The MIC breakpoint above which penicillin therapy is likely to be ineffective for nonmeningeal infections is unknown but is probably $4.0 \mathrm{mg} / \mathrm{L}$ or greater. Such strains are rare in North America $(25,26)$.

Beta-lactam resistance in $H$ influenzae is due almost exclusively to the acquisition and expression of the TEM and ROB beta-lactamase genes (27). The rates of beta-lactamasepositive $H$ influenzae are greater than $40 \%$ (Figure 2) $(27,28)$. The percentage of beta-lactamase-negative, amoxicillinresistant $H$ influenzae, presumably with PBP modifications, is less than $2 \%(27)$. The relevance of this increase in resistance to the impact of the treatment of CAP is questionable. In addition, second- and third-generation cephalosporins have retained excellent activity against the beta-lactamase-positive strains in Canada $(27,28)$.

\section{MACROLIDES}

Macrolides (erythromycin, clarithromycin and azithromycin) inhibit protein synthesis by binding to the $50 \mathrm{~S}$ ribosomal subunits and inhibit elongation of peptide chains. Macrolide resistance in $S$ pneumoniae is due primarily to the acquisition of a gene that is responsible for either efflux of the macrolide out of the cell or a gene that is responsible for modifying the ribosome so as to prevent attachment. Susceptibility is defined as an MIC less than $0.5 \mathrm{mg} / \mathrm{L}$ (Table 1). The mean MICs for strains resistant due to efflux is $10 \mathrm{mg} / \mathrm{L}$ and for those strains resistant due to ribosomal modification is $64 \mathrm{mg} / \mathrm{L}$ (29). Peak levels in serum from 2 to $3 \mathrm{mg} / \mathrm{L}$, from 0.5 to $1 \mathrm{mg} / \mathrm{L}$ and 0.4 $\mathrm{mg} / \mathrm{L}$ are reached at $3 \mathrm{~h}$ after oral doses of erythromycin (500 $\mathrm{mg}$ ), clarithromycin $(250 \mathrm{mg})$ and azithromycin $(500 \mathrm{mg})$, respectively (30). Therefore, the development of resistance is a several-fold increase in the MIC above achievable concentrations in the serum, a finding that may be quite relevant for bacteremia $(31,32)$. However, it may be less relevant for pneumonia because concentrations of macrolides in the intrapulmonary epithelial-lining fluid and alveolar macrophages are 10- to 100-fold higher than that in serum (33-36).

\section{FLUOROQUINOLONES}

The target for the fluoroquinolones is the topoisomerases. Topoisomerases are enzymes in bacteria that are responsible for DNA coiling. There are four topoisomerases, two of which 
TABLE 2

In vitro activity of selected antimicrobials against Streptococcus pneumoniae and Haemophilus influenzae

\begin{tabular}{|c|c|c|c|c|c|}
\hline \multirow[b]{4}{*}{ Antimicrobial } & \multicolumn{5}{|c|}{$\mathrm{MIC}_{90}(\mathrm{mg} / \mathrm{L})$} \\
\hline & \multicolumn{3}{|c|}{ S pneumoniae } & \multirow{2}{*}{\multicolumn{2}{|c|}{$H$ influenzae beta-lactamase production }} \\
\hline & & \multicolumn{2}{|c|}{ Resistant } & & \\
\hline & Susceptible & Intermediate & High & Negative & Positive \\
\hline Amoxicillin & 0.06 & 1 & 2 & 2 & 16 \\
\hline Cefuroxime & 0.12 & 4 & 4 & 1 & 1 \\
\hline Cefprozil & 1 & 8 & 16 & 8 & 8 \\
\hline Cefaclor & 1 & 16 & 16 & 8 & 16 \\
\hline Cefixime & 0.25 & 8 & 16 & 0.25 & 0.25 \\
\hline $\mathrm{TMP} / \mathrm{SMX} \mathrm{X}^{*}$ & 1 & 8 & 8 & 0.25 & 4 \\
\hline Erythromycin & 0.25 & 16 & 16 & 8 & 8 \\
\hline Clindamycin & 0.12 & 0.25 & 8 & ND & ND \\
\hline Tetracycline & 2 & 2 & 16 & 2 & 2 \\
\hline Ciprofloxacin & 2 & 2 & 2 & $\leq 0.06$ & $\leq 0.06$ \\
\hline Levofloxacin & 0.5 & 1 & 1 & $\leq 0.06$ & $\leq 0.06$ \\
\hline Grepafloxacin & 0.25 & 0.25 & 0.25 & $\leq 0.06$ & $\leq 0.06$ \\
\hline Trovafloxacin & 0.12 & 0.25 & 0.25 & $\leq 0.06$ & $\leq 0.06$ \\
\hline
\end{tabular}

*TMP/SMX Trimethoprim/sulphamethoxazole. Data adapted from references 28,71-73

are targets for the fluoroquinolones, topoisomerase II (DNA gyrase) and topoisomerase IV. DNA gyrase consists of two subunits, A and B, which are encoded for by the gyrA and gyrB genes. Topoisomerase IV consists of two subunits, ParC and ParE, which are encoded for by the parC and parE genes. Resistance to the fluoroquinolones results from target modification and/or active efflux of the antimicrobial. Fluoroquinolone resistance in $H$ influenzae is exceedingly rare. Resistance in $S$ pneumoniae is uncommon but does occur. Resistance in the two organisms appears to be due mainly to mutational alterations of the gyrA and parc genes $(37,38)$. As opposed to in Gram-negative organisms, ParC in Gram-positive organisms appears to be the primary target for the fluoroquinolones because mutants with low level resistance always carry a mutation in parc but not in gyrA $(39,40)$. In contrast, mutations in gyrA occur only in strains that have undergone a mutation in parC. In $S$ pneumoniae, the first mutation in parC may result in an increase in the MIC of ciprofloxacin from $1 \mathrm{mg} / \mathrm{L}$ to 4 to 8 $\mathrm{mg} / \mathrm{L}$, and the second mutation in gyrA results in a further increase in the MIC to 64 to $128 \mathrm{mg} / \mathrm{L}(38,41)$.

What does this mean clinically? The earlier fluoroquinolones (eg, ciprofloxacin) were not considered for the treatment of Gram-positive infections because of the antibiotics' marginal activity. Reports of failures to eradicate $S$ pneumoniae, with subsequent superinfections, were reported (42). However, other fluoroquinolones with excellent activity against the respiratory pathogens, including $S$ pneumoniae, have recently become available or will soon be. These fluoroquinolones include levofloxacin, sparfloxacin, gatifloxacin, grepafloxacin, trovafloxacin, clinafloxacin and moxifloxacin. The National Committee for Clinical Laboratory Standards (Villanova, Pennsylvania) (21) has recently provided MIC interpretive standards for $\mathrm{S}$ pneumoniae for levofloxacin, sparfloxacin, grepafloxacin and trovafloxacin (Table 1). These compounds are very potent against isolates of $S$ pneumoniae ( MIC $_{90}$ less than $0.5 \mu \mathrm{g} / \mathrm{L}$ ), including isolates that are resistant to penicillin and macrolides (Table 2) (43). Initial trials support the efficacy of the new fluoroquinolones for the treatment
TABLE 3

Relationship between penicillin susceptibility categories in Streptococcus pneumoniae and resistance of the organism to other antimicrobials or classes of antimicrobials

\begin{tabular}{lccc}
\hline & \multicolumn{2}{c}{$\begin{array}{c}\text { Percentage resistant according to different } \\
\text { categories of penicillin susceptibility }(\mathbf{m g} / \mathbf{L}) \\
\text { Resistant }\end{array}$} \\
Antimicrobial & $\begin{array}{c}\text { Susceptible } \\
(\leq \mathbf{0 . 0 6})\end{array}$ & $\begin{array}{c}\text { Intermediate } \\
\text { High }\end{array}$ \\
\hline Erythromycin & 2 & $\mathbf{( 0 . 1 - 1 )}$ & $(\geq \mathbf{2})$ \\
Clindamycin & $<1$ & 12 & 25 \\
Tetracycline & 2 & 5 & 11 \\
TMP/SMX* & 12 & 54 & 25 \\
Levofloxacin & $<1$ & $<2$ & 97 \\
Grepafloxacin & $<1$ & $<2$ & 3 \\
\hline
\end{tabular}

*TMP/SMX Trimethoprim/sulphamethoxazole. Data adapted from references 58,72

of CAP, including pneumonia due to $S$ pneumoniae (44-50). When resistance develops, the efficacy of these newer quinolones may be compromised (41). However, as with the macrolides, the fluoroquinolones achieve higher concentrations in the alveolar macrophages and the epithelial-lining fluid than in the serum (51-53). This may provide effective concentrations, even though an isolate is resistant in vitro. The ability of fluoroquinolones to concentrate in lung tissue may explain why the reports of failure of ciprofloxacin for the treatment of pneumococcal pneumonia have been so rare, where it has been used either advertently or inadvertently $(42,54-57)$.

\section{TRIMETHOPRIM/SULFAMETHOXAZOLE}

Soon after the introduction of trimethoprim/sulfamethoxazole (TMP/SMX) in the late 1960s, the first isolate of TMP/SMX-resistant $S$ pneumoniae was cultured. Since, resistance has steadily increased and is strongly associated with penicillin resistance (Table 3) (58). A variety of mechanisms of resistance have been identified. The most frequently encountered mechanism is the production of an additional dihydrofo- 
late reductase enzyme that prevents the reduction of dihydrofolate to tetrahydrofolate and is less sensitive than the chromosomal enzyme to inhibition by trimethoprim. Trimethoprim resistance is strongly associated with TMP/SMX resistance in $S$ pneumoniae (59). Strains of $S$ pneumoniae that are resistant to TMP/SMX by this mechanism have MICs ( $64 \mathrm{mg} / \mathrm{L}$ or greater) that are well above the breakpoints for resistance and concentrations achievable in the serum or lung tissue (Table 1) (60). S pneumoniae has been shown to be only moderately susceptible to trimethoprim, and it has been suggested that infections caused by this organism require the synergy induced by the sulfamethoxazole in the TMP/SMX combination for effective therapy (61). In the lung tissues, in a guinea pig model, not only are the concentrations of trimethoprim below the MIC of the resistant strain, but there is also a differential deposition of trimethoprim and sulfamethoxazole (60). In bronchoalveolar lavage fluid and alveolar macrophages, trimethoprim concentration is 10 times higher than sulphamethoxazole concentration. In view of the high rates of resistance (greater than 18\%) and the pharmacokinetics of TMP/SMX, it may be unwise to recommend it as an alternative regimen in the treatment of CAP.

\section{PREVALENCE OF ANTIMICROBIAL RESISTANCE TO RESPIRATORY PATHOGENS IN CANADA}

During the past decade, there has been a marked increase in beta-lactamase-mediated amoxicillin resistance in $\mathrm{H}$ influenzae (Figure 2). Since the late 1980s, beta-lactamase resistance in $H$ influenzae has increased from $15 \%$ to greater than $43 \%(28,62-65)$. Similar increases in penicillin-resistant $S$ pneumoniae have occurred (Figure 1). However, the concomitant increase in resistance to other classes of antibiotics has been of more concern (Table 3, Figure 1). This results in decreased activity of all antibiotics to $S$ pneumoniae, with the exception of the new fluoroquinolones (Table 2).

\section{CONCLUSION}

The emergence of resistance poses a serious threat to the health of Canadians. Reducing the inappropriate use antimicrobials is of the utmost importance. Numerous studies have found that physicians routinely prescribe antibiotics for clinical syndromes in which antimicrobials are known to have no effect $(5,6)$. Physicians overprescribe antibiotics because of patient expectations, insufficient time to discuss with patients why an antibiotic is not needed, and concern that they may misdiagnose bacterial infections where an antibiotic is indicated (66). Therefore, there is an urgent need both to improve prescribing practices and to provide the tools for physicians to diagnosis more accurately those conditions for which an antibiotic is indicated $(66,67)$. National programs in Iceland and Finland have demonstrated that programs to curtail antibiotic use can result in both decreased antibiotic use and antimicrobial resistance $(68,69)$. Similar programs are urgently needed in Canada, otherwise resistance will continue to progress to current first- and second-line antibiotics, and possibly to the newer fluoroquinolones. Clinical studies are required to determine the impact of resistance on the outcome of therapy.

\section{REFERENCES}

1. Breiman RF, Butler JC, Tenover FC, Elliott JA, Facklam RR. Emergence of drug-resistant pneumococcal infections in the United States. JAMA 1994:271:1831-5

2. Jorgensen JH, Doern GV, Maher LA, Howell AW, Redding JS. Antimicrobial resistance among respiratory isolates of Haemophilus influenzae, Moraxella catarrhalis, and Streptococcus pneumoniae in the United States. Antimicrob Agents Chemother 1990;34:2075-80,

3. Anthonisen NR, Manfreda J, Warren CP, Hershfield ES, Harding GK, Nelson NA. Antibiotic therapy in exacerbations of chronic obstructive pulmonary disease. Ann Intern Med 1987;106:196-204

4. van Buchem FL, Knottnerus JA, Schrijnemaekers VJ, Peeters MF Primary-care-based randomised placebo-controlled trial of antibiotic treatment in acute maxillary sinusitis. Lancet 1997:349:683-7.

5. McCaig LF, Hughes JM. Trends in antimicrobial drug prescribing among office-based physicians in the United States. JAMA 1995:273:214-9.

6. Gonzales R, Steiner JF, Sande MA. Antibiotic prescribing for adults with colds, upper respiratory tract infections, and bronchitis by ambulatory care physicians. JAMA 1997;278:901-4.

7. Austrian R, Gold J. Pneumococcal bacteremia with especial reference to bacteremic pneumococcal pneumonia. Ann Intern Med 1964;60:759-70,

8. Bullowa JGM. The reliability of sputum typing and its relation to serum therapy. JAMA 1935;105:1512-8.

9. Fine MJ, Smith MA, Carson CA, et al. Prognosis and outcomes of patients with community-acquired pneumonia. A meta-analysis. JAMA 1996;275:134-41.

10. Fine MJ, Auble TE, Yealy DM, et al. A prediction rule to identify low-risk patients with community-acquired pneumonia. N Engl J Med 1997:336:243-50.

11. Hook EW 3d, Horton CA, Schaberg DR. Failure of intensive care unit support to influence mortality from pneumococcal bacteremia. JAMA 1983;249:1055-7.

12. Kramer MR, Rudensky B, Hadas-Halperin I, Isacsohn M, Melzer E. Pneumococcal bacteremia - no change in mortality in 30 years: analysis of 104 cases and review of the literature. Isr J Med Sci 1987;23:174-80.

13. Klugman KP. Epidemiology, control and treatment of multiresistant pneumococci. Drugs 1996;52(Suppl 2):42-6.

14. Leroy $\mathrm{O}$, Georges H, Beuscart $\mathrm{C}$, et al. Severe community-acquired pneumonia in ICUs: prospective validation of a prognostic score. Intensive Care Med 1996;22:1307-14.

15. Fang GD, Fine $M$, Orloff $J$, et al. New and emerging etiologies for community-acquired pneumonia with implications for therapy. A prospective multicenter study of 359 cases. Medicine (Baltimore) 1990;69:307-16.

16. Wallace RJ Jr, Musher DM, Septimus EJ, et al. Haemophilus influenzae infections in adults: characterization of strains by serotypes, biotypes, and beta-lactamase production. J Infect Dis 1981;144:101-6.

17. Deulofeu F, Nava JM, Bella F, et al. Prospective epidemiological study of invasive Haemophilus influenzae disease in adults. Eur J Clin Microbiol Infect Dis 1994;13:633-8.

18. Petrof EO, Low DE, Canadian Bacterial Surveillance Network, et al. Serotype characterization of Haemophilus influenzae isolates causing invasive disease in Canada following the introduction of $\mathrm{Hib}$ vaccines. 36th Interscience Conference of Antimicrobial Agents and Chemotherapy, New Orleans, Los Angeles, May 19-23, 1996.

19. Dowson CG, Coffey TJ, Spratt BG. Origin and molecular epidemiology of penicillin-binding-protein-mediated resistance to beta-lactam antibiotics. Trends Microbiol 1994;2:361-6.

20. Munoz R, Dowson CG. Daniels M, et al. Genetics of resistance to third-generation cephalosporins in clinical isolates of Streptococcus pneumoniae. Mol Microbiol 1992;6:2461-5.

21. National Committee for Clinical Laboratory Standards. Performance Standards for Antimicrobial Susceptibility Testing; Eighth Informational Supplement [NCCLS Document M100-S8]. Villanova: National Committee for Clinical Laboratory Standards, 1998:1-82.

22. Therapy for children with invasive pneumococcal infections. American Academy of Pediatrics Committee on Infectious Diseases. Pediatrics 1997;99:289-99

23. Goldstein FW, Garau J. 30 years of penicillin-resistant $S$ pneumoniae: myth or reality? Lancet 1997:350:233-4.

24. Strachan SA, Friedland IR. Therapy for penicillin-resistant Streptococcus pneumoniae. J Med Microbiol 1995;43:237-8. [Edit]

25. Goldstein FW. Choice of an oral beta-lactam antibiotic for infections due to penicillin-resistant Streptococcus pneumoniae. Scand J Infect Dis 1997;29:255-7

26. Pallares $\mathrm{R}$, Linares J, Vadillo $\mathrm{M}$, et al. Resistance to penicillin and cephalosporin and mortality from severe pneumococcal pneumonia in Barcelona, Spain. N Engl J Med 1995;333:474-80.

27. Scriver SR, Walmsley SL, Kau CL, et al. Determination of 
antimicorbial susceptibility of Canadian isolates of Haemophilus influenzae and characterization of their $\beta$-lactamases. Antimicrob Agents Chemother 1994;38:1678-80.

28. Davidson RJ, McGeer A, Canadian Bacterial Surveillance Network, Low DE. A cross Canada surveillance of antimicrobial resistance in respiratory tract pathogens. 8th International Congress on Infectious Diseases, Boston, Massachusetts, May 15-18, 1998.

29. Johnston NJ, de Azavedo IC, Kellner JD, Low DE. Prevalence and characterization of the mechanisms of macrolide, lincosamide, and streptogramin resistance in Streptococcus pneumoniae. Antimicrob Agents Chemother 1998;42:2425-6.

30. Yao JDO, Moellering RCI. Antibacterial agents. In: Murray PR, Baron EI. Pfaller MA, Tenover FC, Yolken RH, eds. Manual of Clinical Microbiology, 6th edn. Washington: ASM Press, 1995:1281-307.

31. Jackson MA, Burry VF, Olson LC, Duthie SE, Kearns GL. Breakthrough sepsis in macrolide-resistant pneumococcal infection. Pediatr Infect Dis ] 1996;15:1049-51

32. Reid R Jr, Bradley JS, Hindler J. Pneumococcal meningitis during therapy of otitis media with clarithromycin. Pediatr Infect Dis J 1995; 14:1104-5

33. Fish DN, Gotfried MH, Danziger LH, Rodvold KA. Penetration of clarithromycin into lung tissues from patients undergoing lung resection. Antimicrob Agents Chemother 1994:38:876-8.

34. Fraschini F, Scaglione F, Pintucci G, Maccarinelli G, Dugnani S, Demartini $G$. The diffusion of clarithromycin and roxithromycin into nasal mucosa, tonsil and lung in humans. I Antimicrob Chemother 1991:27(Suppl A):61-5.

35. Morris DL, De Souza A, Jones JA, Morgan WE. High and prolonged pulmonary tissue concentrations of azithromycin following a single oral dose. Eur J Clin Microbiol Infect Dis 1991;10:859-61.

36. Rodvold KA, Gotfried MH, Danziger LH, Servi RJ. Intrapulmonary steady-state concentrations of clarithromycin and azithromycin in healthy adult volunteers. Antimicrob Agents Chemother 1997:41:1399-402.

37. Georgiou M, Munoz R, Roman F, et al. Ciprofloxacin-resistant Haemophilus influenzae strains possess mutations in analogous positions of GyrA and ParC. Antimicrob Agents Chemother 1996;40:1741-4

38. Tankovic J, Perichon B, Duval J, Courvalin P. Contribution of mutations in gyrA and parC genes to fluoroquinolone resistance of mutants of Streptococcus pneumoniae obtained in vivo and in vitro. Antimicrob Agents Chemother 1996;40:2505-10.

39. Westh H, Hougaard DM, Vuust J, Rosdahl VT. Prevalence of erm gene classes in erythromycin-resistant Staphylococcus aureus strains isolated between 1959 and 1988. Antimicrob Agents Chemother 1995;39:369-73

40. Ferrero L, Cameron B, Crouzet J. Analysis of gyrA and grlA mutations in stepwise-selected ciprofloxacin-resistant mutants of Staphylococcus aureus. Antimicrob Agents Chemother 1995;39:1554-8.

41. Wise R, Brenwald N, Gill M, Fraise A. Streptococcus pneumoniae resistance to fluoroquinolones. Lancet 1996;348:1660. [Lett]

42. Lee BL, Padula AM, Kimbrough RC, et al. Infectious complications with respiratory pathogens despite ciprofloxacin therapy. N Engl ] Med 1991;325:520-1. [Lett]

43. Piddock LJ. New quinolones and gram-positive bacteria. Antimicrob Agents Chemother 1994;38:163-9

44. File TM Jr, Segreti J, Dunbar L, et al. A multicenter, randomized study comparing the efficacy and safety of intravenous and/or oral levofloxacin versus ceftriaxone and/or cefuroxime axetil in treatment of adults with community-acquired pneumonia. Antimicrob Agents Chemother 1997:41:1965-72.

45. Adams M, Sullivan J, Henry D, Stewart G, Breisch SA, Maroli AN. Comparison of grepafloxacin with cefaclor in the treatment of community-acquired pneumonia. 37th Interscience Conference on Antimicrobial Agents and Chemotherapy, Toronto, September 28 October 1, 1997.

46. Graham DR, Klein T, Torres A, Niederman M, The Trovan Pneumonia Study Group. A double blind, randomized, multicenter study of nosocomial pneumonia (NOS) comparing trovafloxacin with ciprofloxain \pm clindamycin/metronidazole. 37 th Interscience Conference on Antimicrobial Agents and Chemotherapy, Toronto, September 28 - October 1, 1997

47. Mandell LA, Hopkins WD, Hopkins S. Efficacy of trovafloxacin in patients with community-acquired pneumonia due to penicillin-susceptible and resistant $S$. pneumoniae. 37 th Interscience Conference on Antimicrobial Agents and Chemotherapy, Toronto, September 28 - October 1, 1997

48. Niederman M, Traub S, Ellison WT, Hopkins DW, The Trovan Pneumonia Study Group. A double blind, randomized, multicenter global study in hospitalized community-acquired pneumonia (CAP) comparing trovafloxacin with ceftriaxone + erythromycin. 37 th Interscience Conference on Antimicrobial Agents and Chemotherapy, Toronto, September 28 - October 1, 1997.
49. Sullivan J, Gezon J, Hopkins DW, The Trovan Pneumonia Study Group. A double blind, randomized, multicenter study in ambulatory community acquired pneumonia (CAP) comparing trovafloxacin with clarithromycin. 37th Interscience Conference on Antimicrobial Agents and Chemotherapy, Toronto, September 28 - October 1, 1997.

50. O'Doherty B, Dutchman DA, Pettit R, Maroli A. Randomized, double-blind, comparative study of grepafloxacin and amoxycillin in the treatment of patients with community-acquired pneumonia. I Antimicrob Chemother 1997;40:73-81.

51. Schuler P, Zemper K, Borner K, Koeppe P, Schaberg T, Lode H. Penetration of sparfloxacin and ciprofloxacin into alveolar macrophages, epithelial lining fluid, and polymorphonuclear leucocytes. Eur Respir J 1997:10:1130-6.

52. Andrews JM, Honeybourne D, Brenwald NP, et al. Concentrations of trovafloxacin in bronchial mucosa, epithelial lining fluid, alveolar macrophages and serum after administration of single or multiple oral doses to patients undergoing fibre-optic bronchoscopy. J Antimicrob Chemother 1997;39:797-802.

53. Wise R, Baldwin DR, Andrews IM. Honeybourne D. Comparative pharmacokinetic disposition of fluoroquinolones in the lung. J Antimicrob Chemother $1991 ; 28$ (Suppl C):65-71.

54. Frieden TR, Mangi RJ. Inappropriate use of oral ciprofloxacin. JAMA 1990;264:1438-40.

55. Cooper B, Lawlor $M$. Pneumococcal bacteremia during ciprofloxacin therapy for pneumococcal pneumonia. Am J Med 1989;87:475.

56. Righter J. Pneumococcal meningitis during intravenous ciprofloxacin therapy. Am J Med 1990;88:548.

57. Gordon II, Kauffman CA. Superinfection with Streptococcus pneumoniae during therapy with ciprofloxacin. Am J Med 1990;89:383-4

58. Simor AE, Louie M, The Canadian Bacterial Surveillance Network Low DE. Canadian national survey of prevalence of antimicrobial resistance among clinical isolates of Streptococcus pneumoniae. Antimicrob Agents Chemother 1996:40:2190-3.

59. Adrian PV, Klugman KP. Mutations in the dihydrofolate reductase gene of trimethoprim-resistant isolates of Streptococcus pneumoniae. Antimicrob Agents Chemother 1997:41:2406-13.

60. Dubar V, Lopez I, Gosset P, Aerts C, Voisin C, Wallaert B. The penetration of co-trimoxazole into alveolar macrophages and its effect on inflammatory and immunoregulatory functions. I Antimicrob Chemother 1990;26:791-802.

61. Brumfitt W, Hamilton-Miller JM. Reassessment of the rationale for the combinations of sulphonamides with diaminopyrimidines. I Chemother 1993;5:465-9.

62. Tremblay LD, L'Ecuyer J, Provencher P, Bergeron MG. Susceptibility of Haemophilus influenzae to antimicrobial agents used in Canada. Canadian Study Group. Can Med Assoc J 1990;143:895-901.

63. Syriopoulou V, Scheifele D, Smith AL, Perry PM, Howie V. Increasing incidence of ampicillin resistance in Hemophilus influenzae. I Pediatr 1978:92:889-92

64. Bannatyne RM, Toma S, Cheung R, Hodge D. Antibiotic susceptibility of blood and cerebrospinal fluid isolates of Haemophilus influenzae. J Antimicrob Chemother 1985;15:187-91

65. Scheifele DW. Ampicillin-resistant Hemophilus influenzae in Canada: nationwide survey of hospital laboratories. Can Med Assoc I 1979;121:198-202.

66. Schwartz B. Bell DM. Hughes JM. Preventing the emergence of antimicrobial resistance: A call for action by clinicians, public health officials, and patients. JAMA 1997;278:944-5.

67. Mclsaac WJ, White D, Tannenbaum D, Low DE. A clinical score to reduce unnecessary antibiotic use in patients with sore throat. Can Med Assoc J 1998;158:75-83.

68. Kristinsson KG. Effect of antimicrobial use and other risk factors on antimicrobial resistance in pneumococci. Microb Drug Resist 1997;3:117-23.

69. Seppala H, Klaukka T, Vuopio-Varkila J, et al. The effect of changes in the consumption of macrolide antibiotics on erythromycin resistance in group A streptococci in Finland. N Engl J Med 1997;337:441-6.

70. Mazzulli T, MacDonald KS, Kitching DA, Skulnick M, Low DE, Chua R. Evaluation of the automated vitek immuodiagnostic assay system (VIDAS) for the detection of measles (rubeola) IgG antibodies. Clin Diagn Virol 1995;3:207-13

71. Appelbaum PC. New prospects for antibacterial agents against multidrug-resistant pneumococci. Microb Drug Resist $1995 ; 1: 43-8$

72. Matsumura SO, Pong-Porter S, Trpeski L, de Azavedo JC, The Canadian Bacterial Surveillance Network. The in vitro activity of recently developed antimicorbials against Streptococcus pneumoniae. 37 th Interscience Conference on Antimicrobial Agents and Chemotherapy, Toronto, September 28 - October 1, 1997

73. Wise R, Andrews JM. The activity of grepafloxacin against respiratory pathogens in the UK. J Antimicrob Chemother 1997;40:27-30. 


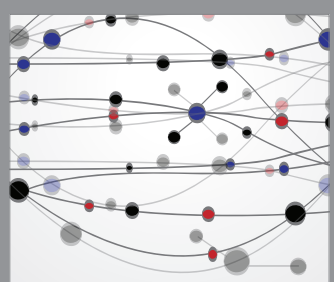

The Scientific World Journal
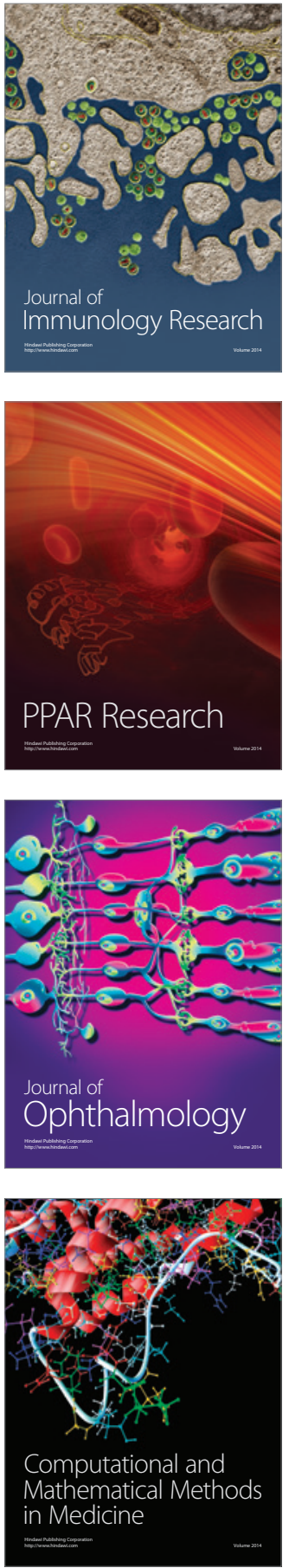

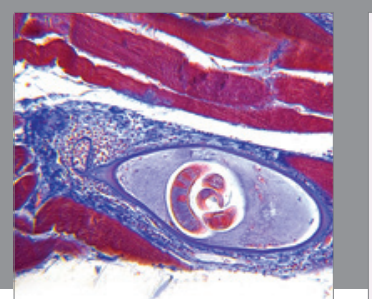

Gastroenterology Research and Practice

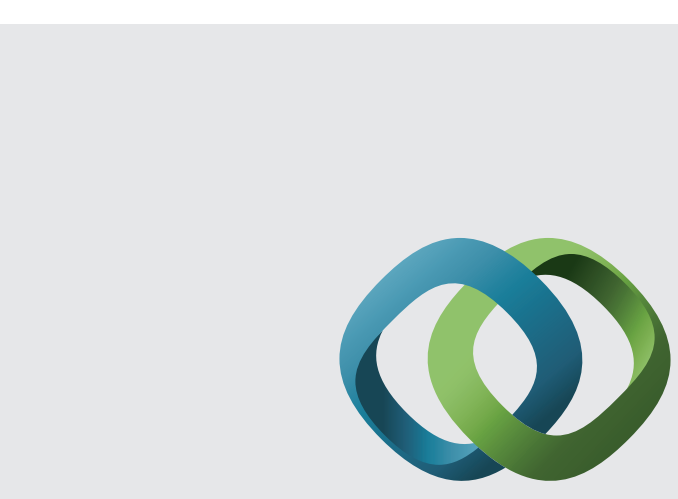

\section{Hindawi}

Submit your manuscripts at

http://www.hindawi.com
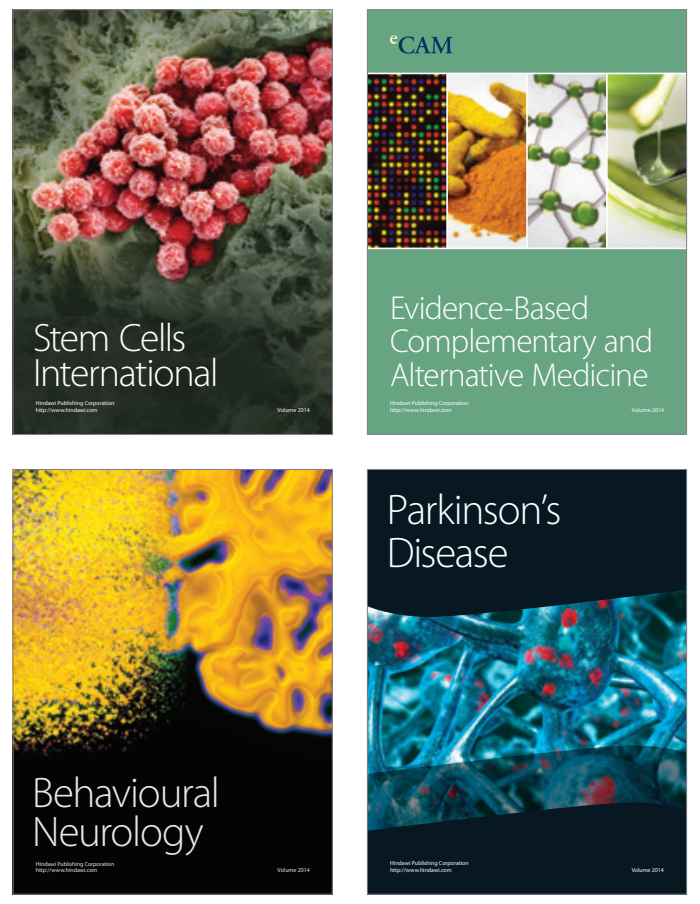
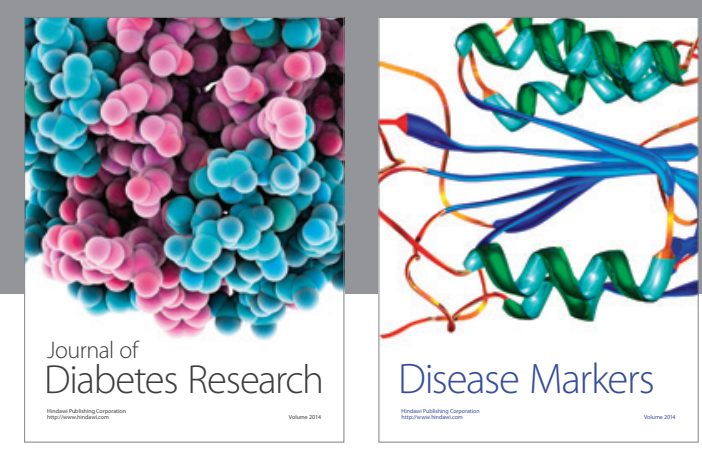

Disease Markers
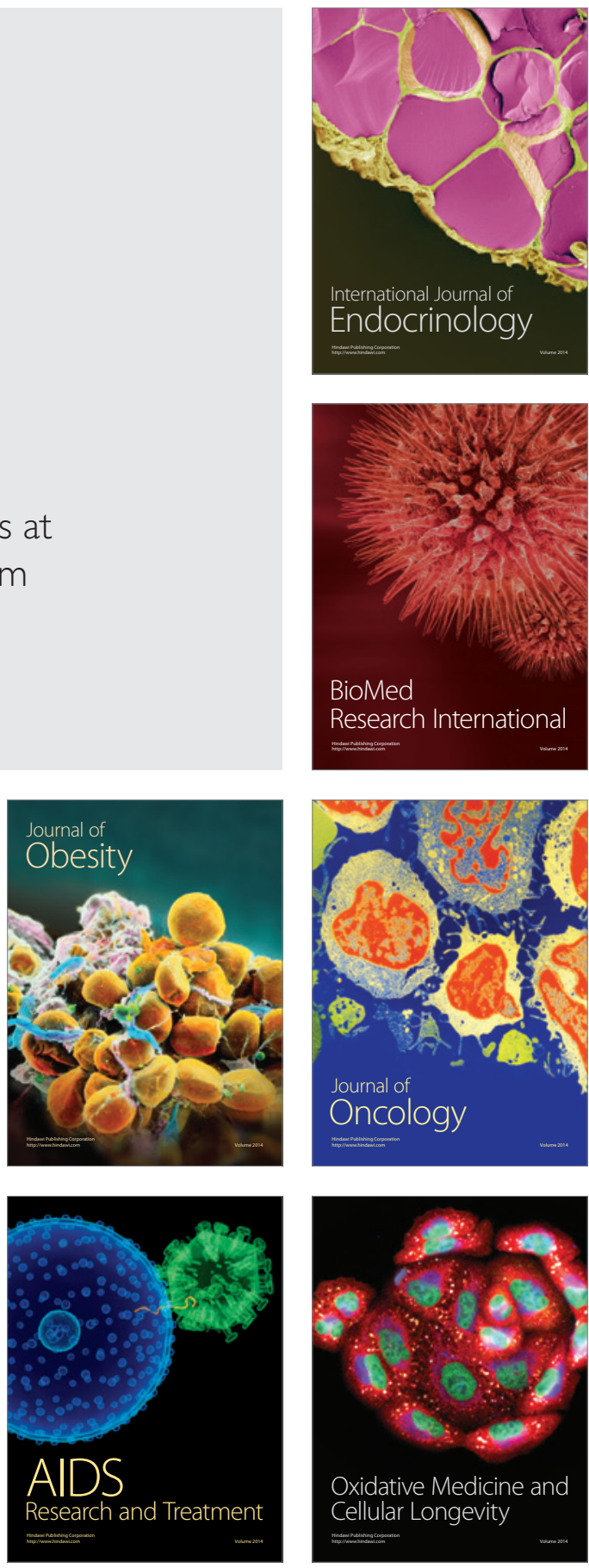